\title{
EKSTRADISI DAN BEBERAPA PERMASALAHANNYA
}

\author{
Deli Waryenti
}

$\overline{\text { Dosen Bagian Hukum Internasional Fakultas Hukum Universitas Bengkulu }}$

Abstract

Extradition is the delivery of an accused or convicted individual who escape to abroad to avoid punishment or trial process. Extradition should be into force whether the two States have made the former treaty related to or based to reciprocity principle. Sometimes, Requested State refuses to surrender the accused person to the Requesting State for many reasons, for example Adrian Kiki who escaped to Australia, but Indonesia could not reach him, although the two States have made a treaty related to. But sometimes, without the treaty of extradition, a State, such as Columbia, surrendered M.Nazaruddin to Indonesia. So basicly, the execution of extradition treaty is uneffective, because it depends on to the good will of the Requested State to do it.

Keywords : Extradition, International Law, National Law.

\section{PENDAHULUAN}

Salah satu masalah yang selalu menimbulkan rasa tidak puas dan komentar di kalangan masyarakat Indonesia pada umumnya, adalah masalah ekstradisi. Masalah ekstradisi mengemuka ketika banyak orang Indonesia yang disangka atau dituduh melakukan kejahatan di Indonesia, baik sebelum, sedang atau telah diproses pengadilan, lalu kemudian melarikan diri ke luar negeri. Setelah mereka berada di luar negeri maka seolah-olah pemerintah tidak berdaya untuk menjangkau orang tersebut, sehingga akhirnya kasus tersebut perlahan-lahan menjadi hilang.

Ada beberapa kasus yang bisa dijadikan contoh, seperti kasus para pengemplang Bantuan Likuiditas Bank Indonesia (BLBI) yang melarikan diri ke Singapura dan Australia. Hendra Rahardja, Adrian Kiki, dan Syamsul Nursalim, dan adalah beberapa nama dari sejumlah pelaku yang melarikan uang Negara dalam jumlah puluhan trilyun rupiah, namun tidak dapat diproses hukum sampai sekarang.

Hendra Rahardja, mantan Direktur BHS Bank yang melarikan diri ke Australia, namun sampai dia meninggal di Australia, yang bersangkutan tidak dapat dipulangkan. Begitu juga pengemplang dana BLBI lainnya sejumlah 1,5 trilyun rupiah yaitu mantan Direktur Bank Surya, Adrian Kiki, yang divonnis seumur hidup oleh Pengadilan Negeri Jakarta Pusat pada tahun 2002, juga berhasil melarikan diri ke Australia, dan bahkan menjadi warga Negara disana. ${ }^{1}$ Namun sampai saat ini yang bersangkutan belum dapat dipulangkan ke Indonesia, walaupun Australia merupakan salah satu dari 5 negara yang sudah melakukan perjanjian ekstradisi dengan

\footnotetext{
${ }^{1}$ Laurencius Simanjuntak, Detiknews.com, Jumat, 9 September 2011, diakses pada Senin, 12 September 2011
} 
Indonesia, selain dari Malaysia, Filipina, Thailand, dan Hongkong. ${ }^{2}$

Sebaliknya, Negara yang belum mengadakan perjanjian ekstradisi dengan Indonesia justru menjadi surga bagi para penjahat ini. Misalnya Singapura, ada beberapa koruptor Indonesia yang justru hidup aman nyaman disana, bahkan dilindungi oleh pemerintah setempat, seperti para pengemplang dana BLBI lainnya, yaitu Syamsul Nursalim (kasus BDNI yang merugikan Negara 6,9 trilyun rupiah dan 96, 7 juta US dollar), Bambang Sutrisno (Bank Surya, 1,5 trilyun rupiah), dan David Nusawijaya (Bank Servitia, sebanyak 1,26 trilyun rupiah). ${ }^{3}$

Sejarah muram mengenai ekstradisi antara Indonesia dengan Singapura sebetulnya sudah berlangsung cukup lama, yaitu pada tahun 1950 ketika Indonesia mengajukan permintaan ekstradisi kepada Inggris atas Turco Westerling $^{4}$ yang waktu itu melarikan diri ke Singapura, sementara Singapura masih merupakan jajahan Inggris. Permintaan itu ditolak oleh Inggris dengan alasan belum adanya perjanjian ekstradisi. ${ }^{5}$

Begitu pula halnya dengan tersangka kasus suap cek perjalanan anggota DPR RI untuk pemilihan Deputy Senior Bank Indonesia (DGS

2 http://id.wikipedia.org/wiki ekstradisi, diakses pada Senin, 12 September 2011.

3 Ahmad Yani Yustiana, Liputan6.com., diakses Selasa, 13 September 2011.

4 Turco Westerling adalah seorang tentara Belanda yang pada waktu Belanda kembali ingin menjajah Indonesia (1949) melakukan pembantaian terhadap ribuan orang warga Makasar.

5 M Budiarto, Masalah Ekstradisidan Jaminan Perlindungan atas Hak Asasi Manusia, Ghalia Indonesia, Jakarta, 1980, halaman 12 .
BI), Nunun Nurbaiti. Sejak kasusnya mencuat sekitar tahun 2009, Nunun Nurbaiti langsung terserang sakit lupa ingatan, sehingga diizinkan berobat ke luar negeri (Singapura). Belakangaan kabarnya yang bersangkutan telah berpindah Negara beberapa kali, seperti Malaysia, Kamboja, dan Vietnam. Terakhir yang bersangkutan terdengar berada di Thailand. Namun sampai akhir tahun 2011 ini yang bersangkutan tidak pernah kembali ke Indonesia, walaupun telah dipanggil secara wajar oleh KPK yang bekerjasama dengan INTERPOL.

Untuk memulangkan Nunun Nurbaiti, KPK melalui pemerintah Indonesia mengajukan permohonan ekstradisi atas tersangka kasus suap pemilihan DGS BI ini. Permohonan pemerintah RI dikabulkan oleh pemerintah Thailand melalui keputusan Pengadilan Negeri Bangkok pada akhir Juli 2011, yang artinya pemerintah Thailand telah mengizinkan untuk membawa pulang Nunun Nurbaiti ke Indonesia. Namun masalahnya adalah bahwa tidak ada pihak yang menjamin bahwa Nunun memang berada di Thailand, sehingga KPKpun belum dapat menangkap dan membawa pulang yang bersangkutan kembali ke Indonesia.

Ekstradisi adalah suatu proses pengembalian seseorang yang disangka atau dituduh melakukan suatu kejahatan. Ekstradisi baru dapat terlaksana setelah Negara tempat si pelaku berada (seterusnya disebut sebagai Negara Diminta/Requested State) telah mengadakan perjanjian internasional mengenai ekstradisi tersebut dengan Negara yang meminta (selanjutnya disebut Negara Peminta/Requesting State), karena Negara Peminta 
memiliki kewenangan untuk mengadili si pelaku. Kewenangan ini didapatkan oleh Negara Peminta karena Negara Peminta merupakan Locus Delicti.

Ekstradisi dibuat dengan tujuan agar pelaku kejahatan bertanggung jawab atas perbuatan yang telah dilakukannya, karena adalah suatu hal yang bertentangan dengan keadilan jika seorang penjahat tidak dihukum atas perbuatannya. Jika tidak ada ekstradisi, maka pelaku kejahatan yang melarikan diri keluar negeri tidak akan mendapatkan hukuman karena Negara tempatnya tersebut tidak memiliki yurisdiksi untuk itu.

Selain itu ekstradisi dibuat agar pelaku kejahatan tidak lagi mempunyai niat untuk melarikan diri jika mengetahui bahwa Negara yang akan didatangi telah memiliki perjanjian ekstradisi dengan Negara tempat dia melakukan kejahatan.

Perjanjian Internasional mengenai ekstradisi antara Negara Diminta dengan Negara Peminta harus memuat aturan-aturan mengenai pengertian ekstradisi, asas dan tujuan ekstradisi, syarat-syarat ekstradisi, proses ekstradisi, jenisjenis kejahatan yang pelakunya dapat diekstradisi, pejabat-pejabat yang terlibat, dan segala sesuatu yang berkaitan dengan ekrtadisi.

Bagi Indonesia sendiri, ekstradisi tidak dapat langsung terlaksana setelah adanya perjanjian ekstradisi dengan Negara Diminta, karena peraturan ketatanegaraan Indonesia mengharuskan adanya proses ratifikasi terlebih dahulu ke dalam Hukum Nasional Indonesia. Hal ini ditegaskan dalam pasal 11 Undang-undang Dasar 1945 Amandemen ke-empat. Pasal 11 ayat (1) berbunyi :
"Presiden dengan persetujuan DPR menyatakan perang, membuat perdamaian dan perjanjian dengan Negara lain."

Begitu juga ayat (2) dari pasal ini yang berbunyi :

"Presiden dalam membuat perjanjian internasional lainnya yang menimbulkan akibat yang luas dan mendasar bagi kehidupan rakyat yang terkait dengan beban keuangan Negara, dan/atau mengharuskan perubahan atau pembentukan undang-undang harus dengan persetujuan DPR."

Dari bunyi pasal 11 ini terlihat bahwa perjanjian internasional yang menyinggung hajat hidup orang banyak juga harus melalui persetujuan DPR. Artinya semua perjanjian internasional mengenai ekstradisi baru dapat diterapkan setelah diratifikasi oleh DPR.

Selain dari keharusan adanya perjanjian internasional antara Negara-negara yang berkaitan, ekstradisi juga dapat terlaksana melalui proses timbal balik (asas resiprositas). Artinya, tanpa perjanjian internasional, sebuah Negara dapat memulangkan seorang pelaku ke Negara Peminta, asal saja kemudian perbuatan itu dibalas oleh Negara Diminta.

Pada dasarnya, ekstradisi merupakan suatu proses yang sangat sulit, rumit, dan berbelit-belit. Hal ini terbukti dari sangat jarangnya Negara-negara melakukan ekstradisi, namun sebaliknya begitu banyak para pelaku kejahatan yang berhasil melarikan diri keluar negeri, dan tidak dapat diproses sebagaimana mestinya karena berbagai sebab, (salah satunya karena berlarutlarutnya proses administrasi dan birokrasi), walaupun telah ada perjanjian ekstradisi antara kedua 
Negara, atau juga karena belum adanya perjanjian ekstradisi antara kedua negara. ${ }^{6}$

Oleh karena itu terlihat bahwa persoalan ekstradisi ini bukanlah persoalan yang sederhana, namun suatu persoalan yang sangat besar, rumit dan berbelit, yang melibatkan Negara-negara. Selain itu dalam proses ekstradisi terkait kepentingan suatu Negara, baik kepentingan ekonomi, politik, dan kepentingan lainnya, sehingga suatu proses ekstradisi dapat mengakibatkan halhal lain seperti membaik atau memburuknya hubungan antar Negara, dan sebagainya, yang akan dibahas lebih lanjut dalam tulisan ini.

\section{PEMBAHASAN}

\subsection{Pengertian Ekstradisi secara Yuridis}

Ada beberapa pengertian ekstradisi, baik yang diatur dalam peraturan internasional maupun nasional, serta yang dikeluarkan oleh para ahli, yaitu :

1. Pasal 1 (a) Harvard Research Draft Convention on Extradition " "Extradition is the formal surrender of a person by a State to another state for prosecution of punishment."

2. Pasal 1 undang-undang nomor 1 tahun 1979 : "Ekstradisi adalah penyerahan oleh suatu Negara kepada Negara yang meminta penyerahan seseorang yang disangka atau dipidana

6 Australia belum bersedia mengembalikan Adrian Kiki dan kawan-kawan, walaupun telah ada perjanjian ekstradisi antara Indonesia dan Australia. Sebaliknya Autralia bersedia menyerahkan warga negaranya Peter Dundas ke Indonesia atas tuduhan kejahatan phedophilia. melakukan suatu kejahatan diluar wilayah Negara yang menyerahkan dan di dalam yurisdiksi wilayah Negara yang meminta penyerahan tersebut karena berwenang untuk mengadili dan memidananya."

3. L. Oppenheim : "Extradition is the delivery of an accused or convicted individual to the state on whose territory he is alleged to have committed, or to have been convicted of, a crime by the State on whose territory the alleged criminal happens for the time to be." 7

4. J. G. Starke : "The term extradition denotes to the process whereby under treaty or upon a basis of reciprocity one state surrenders to another state at its request a person accused or convicted of a criminal offence committed against the laws of the requesting state competent to try the alleged offender." 8

\section{I Wayan Parthiana :} "Ekstradisi adalah penyerahan yang dilakukan secara formal, baik berdasarkan perjanjian ekstradisi yang diadakan sebelumnya atau berdasarkan prinsip timbal balik, atas seseorang yang dituduh melakukan tindak pidana kejahatan (tersangka, tertuduh, terdakwa) atau atas seseorang yang telah dijatuhi hukuman atas kejahatan yang dilakukannya (terhukum, terpidana), oleh

\footnotetext{
${ }^{7}$ Lihat L. Oppenheim, International Law, a tretise, $8^{\text {th }}$ edition, 1960, vol One-Peace, halaman 696.

8 Lihat J.G. Starke, An Introduction to International Law, $7^{\text {th }}$ edition, Butterworths, London ,halaman 348.
} 
negara tempatnya melarikan diri atau berada atau bersembunyi, kepada Negara yang memiliki yurisdiksi untuk mengadili atau menghukumnya, atas permintaan dari Negara tersebut dengan tujuan untuk mengadili atau melaksanakan hukumannya." 9

Dari beberapa definisi yang dikemukakan di atas terlihat bahwa untuk dapat disebut sebagai ekstradisi harus memenuhi beberapa unsur. Unsur-unsur tersebut adalah :

1. Unsur subjek, yaitu :

a. Negara Diminta (Requested State), yaitu Negara tempat pelaku berada atau bersembunyi.

b. Negara Peminta (Requesting State), yaitu Negara yang memiiki yurisdiksi untuk mengadili pelaku karena :

1) merupakan Locus delicti (tempat perbuatan dilakukan);

2) $\mathrm{Si}$ pelaku adalah warga Negara dari Negara Peminta.

2. Unsur objek, yaitu orang yang menjadi objek ekstradisi, yaitu si pelaku kejahatan. Walaupun pelaku dikatagorikan sebagai "objek," bukan berarti pelaku diperlakukan seperti benda yang merupakan objek hukum, namun objek disini bahwa si pelaku dijadikan sebagai objek perjanjian namun dengan memperhatikan berbagai hak dan kewajiban pelaku sebagai seorang manusia.

\footnotetext{
${ }^{9}$ Lihat I Wayan Parthiana, Ekstradisi dalam Hukum Internasional dan Hukum Nasional Indonesia, Penerbit CV Mandar Maju, Bandung, 1990, halaman 12-13.
}

3. Unsur proses ekstradisi, yaitu meliputi berbagai prosedur yang harus dilalui untuk mengembalikan pelaku ke Negara Peminta. Proses ekstradisi terdiri dari :

a.Adanya permintaan dari Negara Peminta kepada Negara Diminta;

b.Permintaan tersebut haruslah didahului oleh perjanjian internasional mengenai ekstradisi antara kedua Negara;

c.Jika kedua Negara belum membuat perjanjian ekstradisi, maka asas resiprositas (timbal balik) dapat diberlakukan;

d.Negara Diminta memproses permintaan Negara Peminta sesuai dengan aturan perundang-undangan yang berlaku di Negara Diminta;

e.Jika Negara diminta bersedia menyerahkan pelaku kejahatan tersebut, maka terjadilah ekstradisi.

4. Unsur tujuan, yaitu tujuan permintaan ekstradisi dari Negara Peminta kepada Negara Diminta. Tujuan ekstradisi adalah untuk mengadili atau menghukum pelaku kejahatan yang melarikan diri. Jika pelaku kejahatan tidak diekstradisi berarti bahwa pelaku kejahatan tidak mempertanggungjawabkan perbuatannya, sehingga tujuan pemberantasan kejahatan tidak tercapai. $^{10}$

\subsection{Perjanjian Ekstradisi}

Perjanjian ekstradisi adalah merupakan perjanjian internasional yang tunduk pada ketentuan

\footnotetext{
${ }^{10} \mathrm{Ibid}$, halaman 13-16.
} 
Konvensi Wina 1969. Definisi mengenai perjanjian internasional diatur dalam Pasal 2 ayat (1a) dari Konvensi Wina 1969 yang berbunyi : "Treaty means an international agreement concluded between States in written form and governed by international law, whether embodied in a single instrument of in two or more related instruments and whatever its particular designation."

Konvensi Wina 1969 kemudian telah diratifikasi oleh Indonesia melalui Undang-undang nomor 37 tahun 1999 tentang Hubungan Luar Negeri. Pasal 1 ayat (3) undangundang ini memberikan definisi perjanjian internasional sebagai berikut :

"Perjanjian internasional adalah perjanjian dalam bentuk dan sebutan apapun yang diatur oleh Hukum Internasional dan dibuat secara tertulis oleh Pemerintah Republik Indonesia dengan satu atau lebih Negara, Organisasi Internasional, atau sbjek Hukum Internasional lainnya, serta menimbulkan hak dan kewajiban pada Pemerintah Republik Indonesia yang bersifat hukum Publik."

Dari bunyi kedua pasal di atas dapat diketahui bahwa untuk dapat disebut sebagai perjanjian internasional harus memenuhi beberapa kriteria, seperti :

1. Dilakukan oleh Negara atau Organisasi Internasional, atau subjek Hukum Internasional lainnya;

2. Dibuat secara tertulis;

3. Tunduk pada Hukum Internasional.

Jika sebuah perjanjian tidak memenuhi unsur-unsur tersebut, maka tidak dapat dikatagorikan sebagai perjanjian internasional. ${ }^{11}$

Jadi perjanjian internasional diperlukan dalam upaya pengembalian seorang tersangka atau terpidana dari luar negeri. Atau dengan kata lain, Ekstradisi tidak dapat dilakukan sebelum ada perjanjian antara Negara Peminta dan Negara Diminta. Namun apakah jika telah ada perjanjian antara kedua Negara maka timbul kewajiban kepada Negara Diminta agar menyerahkan individu yang diminta oleh Negara peminta?

Menurut Grotius, berdasarkan teorinya aut punere aut dedere, maka setiap Negara Diminta harus menyerahkan pelaku yang diminta oleh Negara Peminta, walaupun belum ada perjanjian ekstradisi antara kedua Negara, karena Grotius mendasarkan pada pemikiran bahwa setiap pelaku kejahatan harus dihukum. $^{12}$

Sebaliknya, beberapa ahli Hukum Internasional lain seperti Von Martens berpendapat jika tidak ada perjanjian ekstradisi, maka Negara diminta tidak memiliki kewajiban untuk menyerahkan pelaku kejahatan kepada Negara Peminta. Perjanjian ekstradisi merupakan landasan hukum bagi kedua Negara untuk melakukan ekstradisi terhadap pelaku kejahatan. ${ }^{13}$

Praktek Negara-negara beragam, ada Negara yang bersedia menyerahkan pelaku kejahatan

11 IM Sinclair, The Vienne Convention on the Law of the Treaties, Manchester University Press, USA: Oceana Publications Inc, 1973, halaman 9.

12 Ivan Anthony Shearer, Extradition in International Law, Manchester University Press, Oceana Publication Inc, 1971, halaman 23-24.

${ }^{13}$ Ibid. 
kepada Negara peminta walaupun belum ada perjanjian ekstradisi antara kedua Negara. Sebagai contoh adalah Afrika Selatan, Kanada, Indonesia, dan Kolumbia. ${ }^{14}$ Sebaliknya, Negara-negara yang hanya bersedia menyerahkan pelaku kejahatan setelah ada perjanjian ekstradisi adalah Belanda, Ethiopia, Israel, dan Turki. ${ }^{15}$

Untuk mengatasi keberagaman praktek Negara-negara tersebut serta untuk kepastian hukum, maka pada umumnya Negara-negara melakukan perjanjian ekstradisi, baik secara bilateral maupun secara multilateral. Perjanjian ekstradisi biasanya dilakukan antara Negara-negara yang letaknya berdekatan karena kemungkinan frekwensi larinya pelaku kejahatan ke Negara-negara tetangga tersebut lebih tinggi.

Oleh karena itu Indonesia telah mengadakan beberapa perjanjian ekstradisi dengan Negara-negara tetangga terdekat, yaitu :

1. Perjanjian ekstradisi antara Indonesia dengan Malaysia 1974, yang telah diratifikasi dan diundangkan oleh pemerintah RI melalui Undang-undang nomor 9 tahun 1974;

2. Perjanjian ekstradisi antara Indonesia dengan Filipina 1976, yang telah diratifikasi dan diundangkan oleh Indonesia melalui Undang-undang Nomor 10 tahun 1976;

\footnotetext{
14 Indonesia menyatakan bahwa dapat menyerahkan pelaku kejahatan kepada Negara Peminta berdasarkan hubungan baik (pasal 2 ayat 2 Undang-undang nomor 1 tahun 1979 tentang Ekstradis). Demikian pula Kolumbia, yang terbutki pada kasus M.Nazaruddin, yang dapat dibawa pulang ke Indonesia tanpa melalui proses perjanjian ekstradisi.

${ }^{15}$ Ivan Anthony Shearer, opcit, halaman 28.
}

3. Perjanjian ekstradisi antara Indonesia dengan Thailand 1978, yang telah diratifikasi dan diundangkan melalui Undangundang Nomor 2 tahun 1978;

4. Perjanjian ekstradisi antara Indonesia dengan Australia yang

5. ditandantangani 22 April 1992, yang telah diratifikasi dan diundangkan oleh pemerintah RI melalui Undang-undang nomor 8 tahun 1994;

6. Perjanjian ekstradisi antara Indonesia dengan Hongkong yang ditandatangani 5 Mei 1997, dan telah diratifikasi dan diundangkan oleh Indonesia melalui Undang-undang nomor 1 tahun 2001.

Selain dari perjanjian bilateral, perjanjian ekstradisi juga dapat dilakukan secara multilateral. Kondisi Negara-negara yang berada pada posisi geografis yang berdekatan, memicu Negara-negara ini untuk membuat perjanjian ekstradisi secara multilateral, seperti yang telah dilakukan Negara-negara Arab (The Arab League Extradition Agreement) 1952, Konvensi Ekstradisi Negara-negara Eropa (The European Extradition Convention) 1957, dan Konvensi Ekstradisi Negara-negara Benelux (Belanda, Belgia dan Luxemburg) 1962 (The Benelux Extradition Convention). ${ }^{16}$

Perjanjian-perjanjian ekstradisi yang telah dibuat oleh Negaranegara, baik secara bilateral maupun multilateral, pada umumnya kemudian diratifikasi oleh Negaranegara yang bersangkutan untuk diberlakukan dalam lingkup nasional. Hal ini perlu, mengingat proses penyerahan pelaku kejahatan dari Negara Diminta kepada Negara

\footnotetext{
${ }^{16}$ I Wayan Parthiana, opcit, halaman 21.
} 
Peminta, harus sesuai dengan peraturan perundang-undangan Negara Diminta, walaupun tidak semua Negara Diminta telah memiliki Undang-undang Nasional tentang Ekstradisi.

Selain dari proses ratifikasi yang memakan waktu dan biaya yang cukup besar, pembuatan perjanjian ekstradisi juga melalui proses yang panjang. Sesuai dengan proses perjanjian internasional pada umumnya yang diatur dalam Konvensi Wina 1969, maka ada beberapa tahap yang harus dilalui, yaitu : perundingan (negotiation), penandatanganan (signature), dan pengesahan (ratification). Dalam tahap perundingan, yang perlu diperhatikan adalah faktor bahasa. Jika kedua Negara memiliki bahasa yang berbeda (selain bahasa Inggris), maka perundingan dilakukan dengan menggunakan bahasa masing-masing atau menggunakan bahasa Inggris, sehingga naskah perjanjian nantinya dibuat dalam 3 bahasa. ${ }^{17}$

Dalam tahap penandatanganan, yang berwenang melakukannya adalah utusan Negara yang memiliki kekuatan penuh (full powers). ${ }^{18}$ Jika perjanjian telah ditandangani maka berarti Negara tersebut telah terikat dan harus tunduk pada perjanjian tersebut, sesuai dengan asas yang dijunjung tinggi dalam perjanjian, yaitu asas pacta sunt servanda.

Ada perjanjian internasional yang dapat diterapkan setelah

17 Boer Mauna, Hukum Internasional, Pengertian Peranan dan Fungsi dalam Era Dinamika Global, Alumni, Bandung, 2003, halaman 104-105.

${ }^{18}$ Menurut pasal 7 Konvensi Wina 1969, full powers diwajibkan kepada utusan Negara setingkat Kepala perwakilan Diplomatik, sementara Kepala Negara, Kepala pemerintahan dan Menteri Luar Negeri tidak membutuhkan full powers. melalui 2 tahap saja (perundingan dan penandatanganan), namun ada beberapa perjanjian internasional yang baru dapat diterapkan setelah melalui ketiga tahapan tersebut, salah satu contohnya adalah perjanjian ekstradisi. Perjanjian internasional yang harus melalui 3 tahap ini disebut dengan perjanjian internasional yang Treaty Making Power, yang bermakna bahwa perjanjian internasional tersebut telah mempunyai kekuatan mengikat, baik secara eksternal antara Negara yang mengadakan perjanjian, maupun secara internal, yaitu berlaku bagi Negara-negara yang bersangkutan secara nasional.

Kriteria untuk menentukan apakah suatu perjanjian internasional memerlukan dua tahap atau tiga tahap, ditentukan oleh masingmasing pihak dalam perjanjian yang tercantum dalam Hukum Nasionalnya. Bagi Indonesia, perjanjian ekstradisi merupakan salah satu perjanjian internasional yang Treaty Making Power, sehingga sesuai dengan bunyi Pasal 11 ayat (2) Undang-Undang Dasar 1945 Amandemen ke-empat, maka perjanjian ekstradisi harus diratifikasi oleh DPR.

\subsection{Ekstradisi atas Dasar Timbal Balik}

Jika antara Negara Peminta dan Negara Diminta belum ada perjanjian ekstradisi, maka jalan lain yang dapat ditempuh adalah menyerahkan pelaku kejahatan berdasar asas timbal balik (asas reciprositas). Asas timbal balik berarti bahwa Negara Diminta memberikan itikad baik untuk membantu Negara Peminta, agar dikemudian hari Negara 
peminta dapat melakukan hal yang sama terhadap Negara Diminta.

Menurut I Wayan Parthiana, penyerahan pelaku kejahatan atas dasar asas timbal balik dilakukan dengaan beberapa syarat, yaitu :

1. Belum ada perjanjian ekstradisi antara kedua Negara;

2. Undang-undang ekstradisi kedua Negara tidak melarang penyerahan pelaku kejahatan berdasar asas timbal balik;

3. Ada permintaan ekstradisi yang diajukan oleh Negara Peminta kepada Negara Diminta.

Beberapa Negara ada yang mencantumkan asas timbal balik ini dalam

Undang-undang

Ekstradisinya, seperti Perancis, Austria, Argentina, Belgia, Irak, Jepang, Luxemburg, Meksiko, Peru, Spanyol, Swiss, Thailand, dan Kolumbia. Demikian juga dengan Indonesia, walaupun sesungguhnya mendahulukan adanya perjanjian Ekstradisi seperti yang tercantum dalam Pasal 1 ayat (1) Undangundang nomor 1 tahun 1979 tentang Ekstradisi, yang berbunyi : "Ekstradisi dilakukan berdasarkan suatu perjanjian,"namun dalam pasal 2 ayat (2) berbunyi :

"Dalam hal belum ada perjanjian tersebut dalam ayat (1), maka ekstradisi dapat dilakukan atas dasar hubungan baik dan jika kepentingan Negara Republik Indonesia menghendakinya."

Namun jika dilihat dengan lebih seksama, sesungguhnya ekstradisi atas dasar timbal balik ini memiliki beberapa aspek, yaitu ;

1. Lebih luas jangkauannya, karena permintaan ekstradisi bisa dilakukan kepada semua Negara;

2. Lebih mudah prosesnya, karena tidak memerlukan proses seperti dalam perjanjian ekstradisi;
3. Waktunya juga lebih singkat karena tidak melewati berbagai proses seperti dalam perjanjian ekstradisi;

4. Memberi peringatan kepada para pelaku kejahatan bahwa mereka dapat diekstradisi dengan mudah walaupun belum ada perjanjian ekstradisi sebelumnya antara Negara-negara yang bersangkutan.

\subsection{Asas-asas Ekstradisi menurut Undang-undang nomor 1 tahun 1979}

Ekstradisi harus dilakukan
dengan memperhatikan beberapa asas yang merupakan ketentuan dalam peraturan ekstradisi. Asas-asas tersebut harus dicantumkan di dalam perjanjian internasional mengenai ekstradisi yang dibuat oleh Negaranegara yang berkepentingan. Di Indonesia, asas-asas ekstradisi dapat ditemukan Bab II pasal 2 sampai pasal 17 Undang-undang nomor 1 tahun 1979 tentang Ekstradisi. Adapun asas-asas tersebut adalah :

1. Asas perjanjian (pasal 2 ayat 1). Asas ini mengatur bahwa ekstradisi baru dapat dilaksanakan oleh Negara Peminta dan Negara Peminta setelah terlebih dulu ada perjanjian internasional mengenai ekstradisi antara keduanya;

2. Asas timbal balik (pasal 2 ayat 2). Asas ini mengatur bahwa jika belum ada perjanjian internasional mengenai ekstradisi antara kedua Negara, maka ekstradisi tetap dapat dilaksanakan atas dasar hubungan baik dan demi kepentingan negara;

3. Asas penyerahan pelaku kejahatan (pasal 3 ayat 1). Asas 
ini mengatur bahwa yang dapat diekstradisikan adalah orang yang merupakan pelaku kejahatan dengan status sebagai tersangka atau terpidana;

4. Asas penyerahan pelaku pembantu kejahatan (pasal 3 ayat 2). Asas ini mengatur bahwa orang yang disangka atau dipidana karena melakukan pembantuan, percobaan, dan permufakatan untuk melakukan kejahatan juga dapat diekstradisi, sepanjang perbuatan tersebut merupakan kejahatan di Negara Peminta;

\section{Asas}

kejahatan/kejahatan terdaftar (pasal 4 ayat 1). Asas ini mengatur bahwa ekstradisi dapat dilakukan terhadap pelaku kejahatan yang tindakannya tersebut diatur dalam daftar kejahatan yang dilampirkan dan merupakan bagian tak terpisahkan dari Undang-undang ini. ${ }^{19} \quad$ Kejahatan-kejahatan tersebut merupakan kejahatan biasa.

6. Asas kejahatan tidak terdaftar (pasal 4 ayat 2). Asas ini mengatur bahwa ekstradisi juga dapat dilakukan terhadap kejahatan-kejahatan yang tidak termasuk dalam daftar lampiran Undang-undang ini, namun kejahatan tersebut dinilai sebagai

\footnotetext{
${ }^{19}$ Dalam Lampiran Undang-undang nomor 1 tahun 1979 tentang Ekstradisi ini tercantum sebanyak 32 jenis kejahatan yang pelakunya dapat diekstradisi, seperti pembunuhan, penganiayaan, perkosaan, penculikan, perdagangan manusia, perbudakan, pemerasan, pemalsuan, penipuan, penggelapan, pencurian, perampokan, penyelundupan, pembajakan di laut dan udara, korupsi, perdagangan obat-obat berbahaya, penggunaan senjata api dan bahan peledak tanpa izin, dan sebagainya.
}

kejahatan oleh Negara yang Diminta;

7. Asas tidak menyerahkan pelaku kejahatan politik ${ }^{20}$ (pasal 5 ayat 1), pelaku kejahatan militer $^{21}$ (pasal 6), pelaku kejahatan yang bertalian dengan agama $^{22}$, keyakinan politik, kewarganegaraan, suku bangsa atau golongan tertentu (pasal 14). Orang-orang yang disangka atau dituduh melakukan kejahatankejahatan seperti di atas tidak digolongkan sebagai penjahat karena perbuatan yang dilakukan bukan merupakan tindak pidana biasa. Namun pasal 5 ayat (3) dan dan pasal 6 mengatur bahwa pelaku kejahatan politik dan militer ini dapat dikestradisi jika telah diperjanjikan oleh kedua Negara sebelumnya;

8. Asas tidak menyerahkan warga Negara sendiri (pasal 7). Asas ini menyatakan bahwa jika negara Peminta meminta

20 Kejahatan politik sebenarnya bukan merupakan tindakan yang tergolong kejahatan. Biasanya pelaku adalah orangorang yang berbeda keyakinan politik dengan negaranya. Oleh karena itu perbuatan makar atau pembunuhan kepala Negara/kepala pemerintahan tidak digolongkan sebagai kejahatan politik (pasal 5 ayat 4$)$.

21 Pelaku kejahatan militer sebenarnyaa adalah seorang desersi yang melarikan diri dari kesatuannya di ketentaraan

22 Pelaku kejahatan agama biasanya adalah orang-orang yang mengeluarkan pendapat mengenai suatu agama, namun pendapat tersebut dianggap sebagai hinaan bagi pemeluk agama tersebut. Contoh pelaku kejahatan keagamaan adalah Salman Rushdi, seorang warga Negara Iran yang menulis buku berjudul Satanic Verses (Ayat-ayat Setan) yang isinya diyakini menghina agama Islam. Sejak tahun 1980 Salman Rushdi yang dijatuhi hukuman mati secara in absentia oleh Pengadilan Iran karena bukunya tersebut, meminta suaka ke Inggris dan tidak dapat diekstradisi ke Iran. 
ekstradisi terhadap warga Negara Indonesia, maka Indonesia tidak akan menyerahkan warganya tersebut, kecuali jika pemerintah Indonesia merasa jika pelaku lebih baik diadili di Negara peminta ${ }^{23}$

9. Asas teritorial (pasal 8). Asas ini mengatur bahwa Negara tempat terjadinya kejahatan (baik sebagian atau seluruh kejahatan) berwenang penuh untuk mengadili pelaku, sesuai dengan asas terpenting di dalam hukum pidana, yaitu Lex Locus Delicti (hukum yang berlaku adalah hukum tempat kejahatan dilakukan), sehingga Indonesia dapat menolak permintaan ekstradisi tersebut.

10. Asas ne bis in idem (pasal 9, 10 dan 11). Asas ini mengatur bahwa Indonesia dapat menolak mengekstradisi jika pelaku sedang dalam proses pengadilan untuk kejahatan yang sama (pasal 9), pelaku telah dijatuhi vonnis hakim yang telah mempunyai kekuatan hukum yang tetap untuk kejahatan yang sama(pasal 10), atau pelaku telah selesai menjalani hukumannya untuk kasus yang sama (pasal 11);

11. Asas kadaluarsa (pasal 12). Asas ini mengatur bahwa Indonesia dapat menolak permintaan

\footnotetext{
${ }^{23}$ Aturan tidak menyerahkan warga Negara ini pernah dilakukan oleh Indonesia terhadap kasus Oki (1996) yang dituduh membunuh 3 orang di Los Angeles (AS), namun yang bersangkutan tertangkap dan diadili di Indonesia, karena Indonesia menolak permintaan ekstradisi dari AS. Vonnis hakim terhadap oki adalah hukman mati dan telah dieksekusi sekitar tahun 2006, padahal jika pemerintah menerapkan pasal 7 ayat (2) berkemungkinan Oki tidak dihukum mati di Los Angeles karena AS tidak lagi menerapkan hukuman mati.
}

ekstradisi atas pelaku kejahatan jika menurut pemerintah Indonesia hak untuk menuntut dan mengadili pelaku telah kedaluwarsa;

12. Asas tidak menyerahkan pelaku yang diancam pidana mati di Negara Peminta (pasal 13). Asas ini mengatur bahwa jika kejahatan pelaku diancam hukman mati di Negara Peminta, sedangkan di Indonesia kejahatan tersebut tidak dioancam pidana mati, maka ekstradisi akan ditolak, kecuali Negara Peminta meyakinkan bahwa pelaku tidak akan diancam hukuman mati;

13. Asas kejahatan lain (pasal 15)/ Asas ini mengatur bahwa permintaan ekstradisi akan ditolak oleh pemerintah Indonesia jika ekstradisi dimintakan untuk penuntutan dan pemidanaan kejahatan lain yang tidak tercantum dalam permintaan ekstradisi.

14. Asas tidak menyerahkan pelaku jika akan diserahkan kepada Negara ketiga (pasal 16). Asas ini mengatur bahwa Indonesia akan menolak mengekstradisi seseorang yang tidak akan diadili oleh Negara Peminta, melainkan akan diserahkan kepada Negara ketiga untuk kejahatan lain yang dilakukan diluat permintaan ekstradisi;

15. Asas penundaan ekstradisi (pasal 17). Asas ini mengatur bahwa pelaksanaan ekstradisi akan ditunda jika orang yang diminta untuk diekstradisi sedang menjalani hukuman untuk kejahatan lain yang dilakukan di Indonesia.

Dari beberapa asas ekstradisi telah yang dipaparkan sebelumnya, terlihat bahwa adalah suatu hal yang 
tidak mudah untuk melaksanakan ekstradisi, karena begitu banyak syarat-syarat yang harus dipenuhi, terutama oleh Negara Peminta. Oleh karena itu terlihat bahwa sesungguhnya proses ekstradisi ini sepenuhnya bergantung kepada itikad baik dari Negara Diminta, apakah akan menyerahkan orang yang diminta atau tidak, sesuai dengan syarat-syarat yang telah diatur dalam Undang-undang Negara Diminta.

\subsection{Proses dan syarat-syarat Ekstradisi}

Dalam undang-undang nomor 1 tahun 1979 tentang Ekstradisi, diatur bahwa jika pemerintah Indonesia telah menyetujui untuk menyerahkan seorang pelaku kejahatan yang berada di Indonesia kepada Negara Peminta, maka ada beberapa prosedur yang harus dilalui, yaitu ;

1. Penahanan sementara orang yang akan diekstradisi (pasal 18-20).

Pejabat berwenang dari Negara Peminta harus mengajukan permohonan penahanan sementara terhadap pelaku kejahatan yang akan diekstradisi. Permohonan tersebut diajukan kepada Kaplori atau Jaksa Agung melalui INTERPOL Indonesia, saluran diplomatik, atau melalui jasa lainnya seperti pos, telepon, surat elektronik dan sebagainya. Penahanan sementara ini dilakukan menurut aturan Hukum Acara Pidana Indonesia, karenanya masa penahanan tersebut tidak boleh lebih dari 30 hari.

Penahanan ini juga dilakukan atas jaminan dari Negara Peminta, bahwa Negara tersebut benar-benar akan melakukan ekstradisi terhadap orang tersebut, yang harus dibuktikan melalui dokumendokumen pelengkap yang harus disampaikan secepat mungkin dan tidak boleh melebihi waktu penahanan sementara tersebut. Keputusan atas penahanan sementara ini juga harus diberiahukan kepada Negara Peminta oleh Kapolri atau Jaksa Agung melalui INTERPOL Indonesia, atau saluran diplomatik, atau melalui jasa lainnya.

Jika dalam jangka waktu yang dianggap cukup untuk penahanan, Presiden tidak menerima permintaan ekstradisi dari Negara Peminta melalui Menteri Kehakiman (Hukum dan HAM), maka demi hukum, penahanan terhadap tersangka atau pelaku kejahatan harus diakhiri, dan yang bersangkutan harus dibebaskan oleh Jaksa Agung atau Kapolri (pasal 21).

Pelaku kejahatan yang telah ditahan juga dapat dibebaskan jika diperintahkan oleh Pengadilan, penahanan sudah melewati 30 hari, serta permintaan ekstradisi ditolak oleh Presiden (pasal 34).

2. Pengajuan surat permintaan ekstradisi dari Negara Peminta melalui saluran diplomatik yang ditujukan Kepada Menteri Kehakiman ( Menteri Hukum dan HAM) dan selanjutnya diteruskan kepada Presiden (pasal 21).

Surat permintaan ekstradisi tersebut harus dilengkapi dengan dokumen-dokumen pendukung, yaitu salinan surat perintah penahanan yang dikeluarkan pejabat yang berwenang, uraian kejahatan yang dimintakan untuk diekstradisi, teks ketentuan hukum yang dilanggar oleh pelaku, permohonan penyitaan 
barang bukti, dan surat keterangan kewarganegaraan pelaku. Syaratsyarat tersebut dikenakan kepada pelaku yang disangka melakukan tindak kejahatan.

Sedangkan kepada pelaku yang telah berstatus terpidana, maka dokumen-dokumennya adalah salinan surat putusan pengadilan yang telah mempunyai kekuatan hukum yang tetap, surat keterangan kewarganegaraan dan surat perintah penahanan yang dikeluarkan oleh pejabat yang berwenang (pasal 22);

3. Pemeriksaan terhadap pelaku yang akan diekstradisi (pasal 2528)

\section{Selama dalam proses} penahanan, pelaku kejahatan yang akan diekstradisi akan diperiksa oleh Kepolisian, yang hasilnya berupa berita acara pemeriksaan (BAP), diserahkan kepada Kejaksaan setempat. Berdasarkan BAP ini, selambat-lambat selama 7 hari, Kejaksaan memohonkan surat penetapan Pengadilan untuk menetapkan apakah yang bersangkutan dapat diekstradisi atau tidak. Untuk menjalankan proses persidangan, maka pelaku dipanggil menghadiri sidang pada hari yang telah ditetapkan.

4. Proses persidangan atas BAP (pasal 29-33)

Setelah dipanggil secara patut, maka dalam persidangan yang dilakukan secara terbuka, di depan pelaku yang akan diekstradisi dan dihadiri oleh Jaksa setempat, Hakim akan memeriksa :

a. Identitas pelaku;

b. Kejahatan yang dilakukan bukan termasuk kejahatan yang pelakunya tidak dapat diekstradisi;

c. Hak penuntutan belum kedaluwarsa;

d. Pelaku belum pernah dijatuhi hukuman untuk kasus yang dimintakan ekstradisi;

e. Kejahatan tersebut diancam pidana mati di Negara Peminta, sedangkan di Indonesia tidak;

f. Orang tersebut sedang diperiksa di Indonesia atas kejahatan yang sama.

Dari hasil pemeriksaan tersebut Hakim akan memutuskan apakah yang bersangkutan dapat diekstradisi atau tidak.

5. Pertimbangan dari Menteri Kehakiman (Menteri Hukum dan HAM), Menteri Luar Negeri, Jaksa Agung, dan Kapolri, terhadap penetapan Hakim, jika Hakim menetapkan bahwa yang bersangkutan dapat diekstradisi (pasal 36 ayat 1 );

6. Keputusan Presiden untuk menentukan apakah yang bersangkutan dapat diekstradisi atau tidak (pasal 36 ayat 2). Keputusan ini kemudian diberitahukan kepada Negara Peminta melalui saluran diplomatik.

7. Penyerahan orang yang diekstradisi (pasal 40-41). Jika permintaan ekstradisi disetujui oleh Presiden, orang yang diekstradisi akan diserahkan kepada pejabat yang berwenang dari Negara Peminta, di tempat dan waktu yang telah ditetapkan oleh Menteri Kehakiman (Hukum dan HAM) Indonesia. Jika yang bersangkutan tidak diambil pada waktu yang ditentukan, maka setelah 30 hari, 
demi hukum, pemerintah Indonesia akan melepaskan pelaku, dan Negara Peminta tidak dapat mengajukan permintaan ekstradisi lagi untuk orang yang sama.

Dari beberapa prosedur yang telah dipaparkan di atas, terlihat bahwa untuk melakukan ekstradisi, begitu banyak pihak yang dilibatkan, mulai dari Presiden, Menteri Luar Negeri, Menteri Kehakiman (Hukum dan HAM), Jaksa Agung, Kapolri, INTERPOL, Perwakilan diplomatik, Pengadilan setempat, Kejaksaan setempat, dan Kepolisian setempat. Dengan demikian terlihat bahwa proses ekstradisi ini begitu rumit, berbelit dan memakan waktu yang cukup lama.

\subsection{Kasus-kasus Ekstradisi}

Salah satu kasus ekstradisi terbesar yang cukup menghebohkan adalah kasus ekstradisi Jenderal Manuel Noriega, yang merupakan mantan diktator di Panama (19831989). Pada akhir masa pemerintahannya, Noriega ditangkap dan diekstradisi ke Amerika Serikat atas tuduhan kejahatan narkoba, dan melalui pengadilan Florida, dijatuhi hukuman penjara selama 21 tahun. Noriega menjalani hukumannya di penjara Miami, Florida.

Pada tanggal 7 Juli 2010, Perancis juga menjatuhkan pidana selama 7 tahun pada Noriega atas tuduhan kejahatan pencucian uang (money laundry). Untuk menjalani hukuman tersebut, maka Noriega langsung diekstradisi ke Perancis. Namun baru setahun menjalani hukumannya di Perancis, pada Oktober 2011 lalu, Panama meminta agar Noreiga diekstradisi ke Panama atas tuduhan korupsi, penggelapan, dan pembunuhan terhadap 3 orang lawan politiknya selama dia berkuasa, dimana Noreiga telah diadili secara in absentia dan dijatuhi vonis hukuman penjara selama 60 tahun. Dan izin ekstradisi dari Perancis ke Panama telah dikeluarkan oleh Pengadilan tinggi Perancis pada 23 Oktober 2011. ${ }^{24}$

Dari kasus Noriega ini terlihat beberapa hal yang perlu diperhatikan:

1. Dominasi Negara besar terhadap Negara kecil;

Ekstradisi yang dilakukan Amerika Serikat terhadap Noriega pada 1989 memperlihatkan bahwa Amerika Serikat melalui Presiden waktu itu, George Bush telah melakukan tindakan pelanggaran Hukum Internasional, yaitu melaksanakan kedaulatannya di Negara lain. Noreiga masih berstatus Presiden Panama ketika dia "diculik" dan "dibawa paksa" ke Amerika Serikat. Hukum Internasional menerapkan asas Par In Parem Non Habet Imperium, yang artinya bahwa suatu Negara tidak dapat memaksakan kekuatannya kepada Negara lain. Terlepas dari kesalahan Noriega yang dituduh Amerika Serikat sebagai pemasok heroin, maka tindakan Amerika Serikat tersebut dapat digolongkan sebagai tindakan dominasi Negara besar terhadap Negara kecil yang bertentangan dengan Hukum Internasional. ${ }^{25}$

\footnotetext{
${ }^{24}$ Harian Kompas, 24 Oktober 2011

25 Sebenarnya tindakan Amerika Serikat terhadap Negara kecil yang menentangnya sudah sering terjadi, seperti invasi yang dilakukan Amerika Serikat terhadap Irak, dan Afganistan. Hal serupa juga dilakukan oleh Cina terhadap Tibet.
} 
2. Ekstradisi atas Noriega adalah tidak sah ;

Ekstradisi atas Noriega dilakukan berdasar prinsip-prinsip politik, diplomatik dan moral ${ }^{26}$ bukan berdasar prinsip hukum, terutama Hukum Internasional. Jika ekstradisi Noriega dilakukan bukan atas dasar prinsip Hukum (Internasional), maka disini terlihat bahwa sebenarnya belum ada perjanjian ekstradisi antara Amerika Serikat dan Panama, yang berarti bahwa proses ekstradisi tersebut adalah tidak sah, sehingga Amerika Serikat melakukan lagi pelanggaran Hukum Internasional.

3. Negara-negara besar bekerja sama menindas Negara kecil ;

Ekstradisi Noriega dari Amerika Serikat ke Perancis yang dilakukan secara langsung memperlihatkan bahwa Negaranegara besar memperlakukan Negara kecil seperti "membagi-bagi kue antar sesama mereka" tanpa memperhatikan hak dan kedaulatan Negara kecil. Panama sebagai Negara asal dari Noriega seperti tidak memiliki hak apa-apa untuk membela warga negaranya sendiri.

4. Ekstradisi dilakukan berkali-kali atas satu orang untuk tindak pidana yang berbeda:

Sesuai dengan asas ekstradisi, pada dasarnya seseorang dapat dikestradisi lebih dari satu kali, sepanjang tidak terjadi ne bis in idem atas ekstradisi tersebut.

\footnotetext{
26 Pernyataan Presiden Goerge Bush ini dilontarkan setelah Amerika Serikat mendapat banyak kecaman dari Negara lain. Seterusnya lihat Romli Atmasasmita, Pengantar Hukum Pidana Internasional, Eresco, Bandung, 1995, halaman 85.
}

5. Ekstradisi Noriega dari Perancis ke Panama sebelum Noriega selesai menjalani hukumannya di Perancis menunjukkan bahwa Panama sebagai Negara asal Noriega berani memperlihatkan kedaulatannya atas Negara besar seperti Perancis, sehingga berani meminta ekstradisi atas Noriega agar yang bersangkutan menjalani hukumannya di negaranya sendiri. ${ }^{27}$

Selain dari kasus Noriega tersebut, sebenarnya Indonesia telah pernah berhasil mengekstradisi seorang pelaku kejahatan warga Negara Australia, Peter Dundas. Tersangka merupakan pelaku kasus pencabulan 3 (tiga) orang anak di bawah umur (phedopillia) yang dilakukannya di Lombok dari tahun 1997 sampai dengan 2006. Perbuatan tersebut adalah tindak pidana berdasarkan Pasal 82 UndangUndang Nomor 23 Tahun 2002 tentang Perlindungan Anak dan Pasal 292 KUHP dengan ancaman hukuman maksimal 15 (lima belas) tahun penjara. Peter Dundas Walbran, diekstradisi dari Australia ke Indonesia pada 21 Oktober 2011. Peter adalah warga Negara Australia dan merupakan mantan tenaga pengajar di Australian International School (AIS) di Jakarta dan telah menjadi buronan sejak tahun 2007 dan telah dimintakan ekstradisinya sejak tahun 2008.

Ekstradisi Peter Dundas Walbran mengalami banyak kendala mengingat tersangka adalah Warga Negara Australia dan keberadaan yang bersangkutan di Australia baru

27 Hal ini sesuai dengan pendapat I Wayan Parthiana, bahwa seseorang lebih senang menjalani hukuman di negaranya sendiri dari pada di Negara lain. Selanjutnya lihat I Wayan Parthiana, op cit, halaman 8. 
diketahui, yaitu di daerah pinggiran Australia, di Lakeview Parade. Peter Dundas berhasil ditangkap otoritas kepolisian federal di Australia pada tanggal 3 Maret 2010 di Sidney Airport Australia pada saat tersangka akan melarikan diri keluar wilayah Australia. Penangkapan ini berhasil dilakukan berdasarkan permohonan penahanan sementara (provisional arrest) dari Kementerian Hukum dan Hak Asasi Manusia serta tindak lanjut atas kerjasama yang erat antara pihak Attorney General's Australia, Kementerian Hukum dan Hak Asasi Manusia, dan Kepolisian Negara Republik Indonesia. ${ }^{28}$

Pengekstradisian Peter Dundas Walbran, berdasarkan Keputusan Menteri Kehakiman Australia tanggal 22 Agustus 2011 dan diputuskan diserahkan kepada petugas Kepolisian Negara Republik Indonesia di Bandara Internasional Sidney.

Dari

keberhasilan

mengekstradisi Peter Dundas Walbran ini dapat diperhatikan beberapa hal, yaitu :

1. Indonesia berhasil melakukan ekstradisi;

2. Australia melaksanakan asas pacta sunt servanda dengan konsekwen ;

3. Australia melakukan pelanggaran terhadap peraturan Nasionalnya sendiri dan hukum Internasional, yaitu menyerahkan warga negaranya untuk dihukum di Negara lain. Padahal hukum Internasional dan Undangundang ekstradisi Negara mannapun melarang penyerahan warga negaranya sendiri untuk diekstradisi. ${ }^{29}$

\footnotetext{
${ }^{28}$ Kompas, 22 Oktober 2011.

${ }^{29}$ Lihat lagi kasus Oki yang telah disinggung sebelumnya. Kasus yang sama juga pernah
}

4. Hal penting yang harus diperhatikan atas keberhasilan ekstradisi ini, yaitu bagaimana mekanisme ekstradisi dapat diterapkan bagi pengembalian tersangka atau terpidana buronan tindak pidana korupsi yang hingga saat ini masih banyak melarikan diri diluar negeri, khususnya buronan tindak pidana korupsi BLBI yang saat ini sulit untuk dikembalikan ke Indonesia.

Namun tanpa perjanjian ekstradisi, Indonesia pernah memulangkan sesorang yang disangka melakukan tindak pidana dan kemudian melarikan diri ke luar negeri. Kasus ini menimpa mantan bendahara partai Demokrat, $\mathrm{M}$. Nazaruddin. M. Nazaruddin yang disangka terlibat dalam kasus suap pembangunan Wisma Atlet di Palembang, sebelum diperiksa, telah melarikan diri keluar negeri. Tercatat ada beberapa Negara yang didatangi M. Nazaruddin, seperti Singapura, Malaysia, Thaiand, Vietnam, Kamboja, bahkan dikabarkan $M$. Nazaruddin juga sempat bersembunyi di Pakistan. Tapi akhirnya yang bersangkutan diketahui berada di kota Cartagena, Columbia, Amerika Selatan. Pada akhir Juli 2011, atas kerjasama yang baik antara POLRI, INTERPOL dan pemerintah Kolumbia, $\mathrm{M}$. Nazaruddin dipulangkan kembali ke Indonesia tanpa mengalami kesulitan berarti.

terjadi antara Libya dan Amerika Serikat, dimana Amerika Serikat menuduh 2 orang warga Negara Libya melakukan pembajakan di pesawat udara yang berbendera Amerika Serikat. Namun pemerintahan Muamar Khadafi menolak keras pengembalian kedua warga Negara Libya tersebut karena bertentangan dengan Hukum Internasional dan Hukum Nasional Libya. 
Dari kasus M. Nazaruddin ini juga dapat diperhatikan beberapa hal, yaitu :

1. Pelaku dapat dikembalikan tanpa perjanjian dan proses ekstradisi;

2. Pelaku dapat dikembalikan melalui jalur timbal balik, sehingga Indonesia saat ini memiliki kewajiban yang sama terhadap Kolumbia di masa depan;

3. Pelaku dapat dikembalikan tanpa melalui proses yang panjang, rumit, dan berbelit;

4. Kolumbia merupakan Negara yang menghormati hukum Internasional dan memiliki itikad baik untuk memberantas kejahatan;

5. Indonesia dan Kolumbia memiliki hubungan yang baik.

\section{PENUTUP}

\subsection{Simpulan}

Ekstradisi adalah suatu jalan yang ditempuh oleh Negara-negara yang ingin mengembalikan pelaku kejahatan ke Negara locus delicti. Namun pelaksanaan ekstradisi ini sering mengalami kendala terutama bagi Negara berkembang seperti Indonesia yang tidak mempunyai posisi tawar yang baik, sehingga perjanjian-perjanjian ekstradisi yang pernah dibuat tidak mempunyai kekuatan. Sebaliknya, Negara-negara maju dan mempunyai posisi tawar yang tinggi, dapat dengan mudah melakukan ekstradisi, walaupun dengan melanggar Hukum Internasional.

Ekstradisi juga ternyata tidak efektif karena :

1. Bergantung kepada perjanjian internasional yang harus sudah dibuat sebelumnya;
2. Memakan biaya yang tinggi karena melibatkan begitu banyak lembaga-lembaga Negara;

3. Memakan waktu dan tenaga yang cukup besar karena proses yang rumit dan berbelit;

4. Sangat bergantung kepada itikad baik, keinginan dan kepentingan dari Negara yang Diminta;

5. Sangat sulit untuk dilaksanakan karena memiliki banyak asas yang membuat seorang pelaku kejahatan tidak dapat diekstradisi;

6. Negara Diminta sering memposisikan diri sebagai pihak yang lebih tinggi, sehingga mengajukan penawaran yang merugikan Negara Peminta;

7. Pelaku kejahatan akan melarikan diri ke Negara yang diketahuinya belum mengadakan perjanjian ekstradisi dengan Negara locus delicti dan akan menghindari Negara yang diketahuinya telah mengadakan perjanjian ekstradisi dengan Negara locus delicti;

8. Penolakan dari Negara Diminta untuk mengembalikan seseorang yang diminta untuk diekstradisi akan berakibat buruk pada hubungan bilateral kedua Negara, apalagi jika sebelumnya telah ada perjanjian ekstradisi.

\subsection{Saran}

$$
\begin{aligned}
& \text { Oleh karena itu disarankan } \\
& \text { agar Negara-negara } \\
& \text { mengutamakan : }
\end{aligned}
$$

1. Pemberantasan kejahatan dengan tidak memandang apakah Negara Peminta dan Negara Diminta telah mengadakan perjanjian ekstradisi sebelumnya;

2. Itikad baik, demi hubungan internasional yang lebih baik antara Negara-negara, sepanjang 
penyerahan orang tersebut tidak merugikan Negara yang Diminta;

3. Menyerahkan orang yang diminta melalui proses timbal balik, yang lebih hemat, praktis dan tidak berbelit, sekaligus meningkatkan fungsi INTERPOL.

\section{DAFTAR PUSTAKA}

\section{Buku-Buku}

Boer Mauna, Hukum Internasional Pengertian Peranan dan Fungsi dalam Era Dinamika Global, Alumni, Bandung, 2003;

IM Sinclair, The Vienna Convention on the Law of the Treaties, Manchester United Press, 1973;

Ivan Anthony Shearer, Extradition in International Law, Manchester United press, 1971;

I Wayan Parthiana, Ekstradisi dalam Hukum Internasional dan Hukum Nasional Indonesia, Mandar Maju, Bnadung, 1990;

JG Starke, Introduction to International Law, $7^{\text {th }}$ ed. Butterworths and Co Ltd, $4^{\text {th }}$ ed., London, 1958;

M Budiarto, Masalah Ekstradisi dan Jaminan Perlindungan atas
Hak Asasi Manusia, Ghalia Indonesia, 1980;

Oppenheim, International Law a Treatise, $8^{\text {th }}$ ed. Vol. 1 Peace, 1960;

Romli Atmasasmita, Pengantar Hukum Pidana internasional, PT Eresco, Bandung, 1995;

Wasito, Konvensi-konvensi Wina tentang Hubungan Diplomatik, Hubungan konsuler dan hukum Perjanjian/Traktat, Andi Offset, Yogyakarta, 1984;

\section{Peraturan Perundang-Undangan}

Undang-undang Dasar 1945 Amandemen ke 4;

Undang-undang nomor 1 tahun 1979 tentang Ekstradisi;

\section{Artikel/Website/Koran}

Ahmad Yustiana, Liputan6.com, diakses Selasa, 12 September 2011;

Laurencius Simanjuntak, detiknews.com, Jumat, 9 September 2011, diakses Senin, 12 September 2011;

Kompas, 22 dan 24 oktober 2011; http://id.Wikipedia.org/wiki/ekstradis i, diakses Senin, 11 September 2011. 